\title{
Assessment of the Coastal Marchica Watershed through Ecotoxicological Indices of Trace Elements in Superficial Sediments
}

\author{
Bouchra Oujidi ${ }^{1,}$, ,Mohamed Kabriti $^{2}$, Mounia Tahri $^{3}$, Abdelfettah Bensaber $^{2}$, Abdelfettah Benchrif $^{3}$, Mostafa $_{\text {Layachi }}{ }^{4}$, \\ Mohamed Maanan ${ }^{5}$,Hocein Bazairi ${ }^{1}$, Nadia Mhammdi ${ }^{6}$, and Maria Snoussi ${ }^{1}$ \\ ${ }^{1}$ Mohammed V University in Rabat, Faculty of Sciences. 4 Avenue Ibn Battouta, B.P. 1014 RP 10000, Morocco. \\ ${ }^{2}$ National Laboratory for Studies and Pollution Monitoring (LNESP), Av. Mohamed Ben Abdellah Er-regragui Madinat Al-Irfane \\ Rabat, Morocco. \\ ${ }^{3}$ National Center for Energy, Sciences and Nuclear Techniques (CNESTEN), BP 1382, RP 10001 Rabat, Morocco. \\ ${ }^{4}$ National Institute of Fisheries Research (INRH), 13Bd Zerktouni, BP 493, Nador, Morocco. \\ ${ }^{5}$ University of Nantes LETG, UMR 6554, BP 81227, France. \\ ${ }^{6}$ Mohammed V University in Rabat, Institut Scientifique, GEOPAC Research Center, Geophysic and Natural Hazards Laboratory, \\ Morocco.
}

\begin{abstract}
This study analyses the seasonal distribution in the superficial sediments of the Marchica watershed of trace and major elements, grain size, and total organic carbon. Samples were taken during the wet and dry seasons of 2018 in the mainstream valleys carrying the discharges to the Marchica Lagoon. Ecotoxicological indices (Enrichment Factor, Contamination Factor, Pollution-Load Index) and sedimentquality guidelines were used to evaluate the ecotoxicological risk. The results revealed during both wet and dry seasons contamination by lead in all stream valleys. The northwest stream valley, characterized by some industrial activities, and the stream valley crossing the abandoned mine were the most polluted by zinc and copper. Minimal pollution for $\mathrm{Cr}, \mathrm{Co}$, and $\mathrm{Ba}$ was found during both the wet and dry seasons. Despite the restoration actions achieved around the Ramsar site of Marchica lagoon during the last decades, the watershed continues to have a negative impact on this ecosystem. Therefore, an environmental management strategy is necessary, taking into account the rehabilitation of the abandoned mining sites, the rational use of pesticides and fertilizers in agriculture, and the environmental responsibility of industrial companies, especially those installed before the implementation of the national law on environmental impact studies.
\end{abstract}

\section{Introduction}

Watersheds surrounding the coastal lagoons have experienced intense urbanization in recent years due to the ecosystem services offered by these ecosystems. However, this urbanization accompanied by the intensification of human activities around coastal lagoons has impacted their structure and function and compromised their ecological integrity [1-2]. Sediment flows in rivers reflect natural or human-induced changes in their watersheds [3]. The characterization of terrestrial sediment inputs to the seas is essential for watershed managers because of the harmful effects of sediments on nearshore marine ecosystems [4].

The Marchica watershed constitutes an example with a population of approximately 400000 from cities around the Ramsar site of the Marchica lagoon. The watershed covers an area of $700 \mathrm{~km}^{2}$ and is formed by four morphological structures, the volcanic massif of Gourougou in the northwest, the massif of Beni Boulffrour in the west; the Kebdana massif in the south; and the Bouarg plain in the southwest $[5,6]$.
The hydrographic network of the Marchica watershed is composed of several stream valleys called wadis, the majority of which have important contributions during rainy periods [7]. The geochemical assessment of the sediment inputs from the Marchica watershed, which are the main sources of pollution in the Marchica Lagoon, is crucial for protecting this Ramsar site and conserving its biodiversity.

\section{Objectives}

The objectives of this study are to assess Marchica watershed sediment characteristics through:

1. analysis of the seasonal distribution of trace elements $(\mathrm{Pb}, \mathrm{Cu}, \mathrm{Zn}, \mathrm{Cr}, \mathrm{Co}, \mathrm{Ba})$, major elements, grain size, and total organic carbon in the superficial sediments of the Marchica watershed;

2. ecological risk assessment of trace elements in superficial sediments;

3. identification of highly polluted areas.

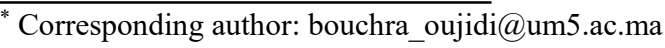




\section{Methodology}

Superficial sediments $(0.5 \mathrm{~cm})$ were sampled during the wet (March) and dry (July) seasons of 2018 in the main wadis of the Marchica watershed carrying the discharges to the Marchica lagoon through a representative station for each one (Fig. 1). The climate is Mediterranean with hot and dry summers and mild and rainy winters.

Major elements analysis was carried out using Bruker S1 Turbo SD hand-held X-ray fluorescence (HHXRF) spectrometer. Trace elements analysis were realized by an Agilent 4200 microwave plasma atomic emission spectrometer (MP-AES). Granulometry analysis was measured by a laser particle size analyzer (Malvern Mastersizer 2000) and Total organic carbon analysis by a LECO carbon analyzer. Analysis details are given in [8].

Enrichment Factor (EF) [9], Contamination Factor (CF) [10] and Pollution-Load Index (PLI) [11] were studied for trace elements (TEs) to access ecological risk:

$E F=(C T E s l / C F e)$ Sample $/(C T E s / C F e)$ Background

CF=CTEs Samplen /CTEs Background

$P L I=(C F 1 \times C F 2 \times C F 3 \times \ldots \times C F n) 1 / n$

Normalization using iron was calculated to quantify the anthropogenic metal pollution from the natural variability of trace elements, and reference values were taken from Rudnick and Gao (2003) [12]. Sediment concentrations were compared with sediment-quality guidelines (SQGs) for freshwater ecosystems to evaluate the ecotoxicological risk as reported by Macdonald et al. (2000) [13].

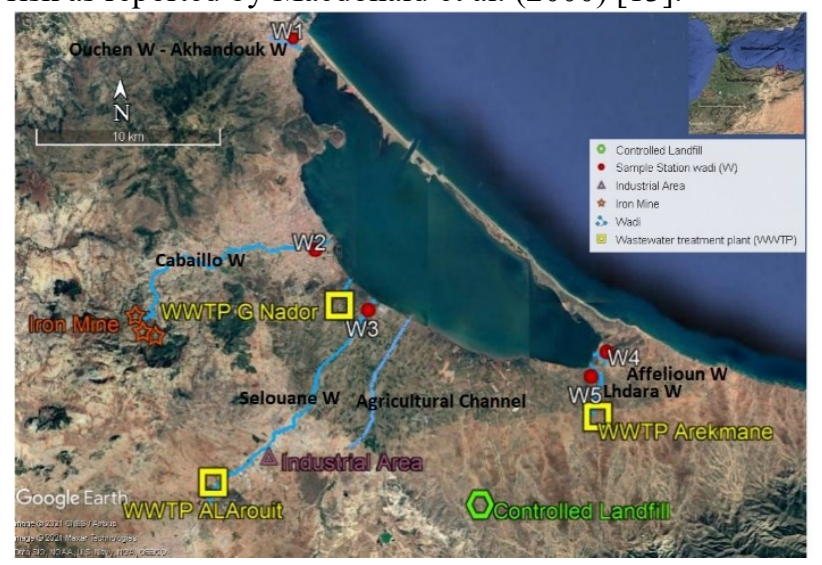

Fig. 1. Map of Coastal Marchica Watershed.

\section{Results}

\subsection{Granulometry and TOC}

The granulometric distribution sediment in the Marchica watershed showed that all sampling stations were classified as muddy sand facies during the wet season and sandy mud during the dry season except the first station, which was classified as sand during the wet season.

The TOC sediment results ranged from $0.70 \%$ to $4.58 \%$ during the wet season and from $1.82 \%$ to $10.10 \%$ during the dry season.

\subsection{Major and Trace Elements}

The average concentrations of major elements (\%) during the wet and dry seasons showed the following pattern $\mathrm{Si}$ $(17.63)>\mathrm{Ca}(13.64)>\mathrm{Al}(4.54)>\mathrm{Fe}(3.90)>\mathrm{K}(1.88)>$ $\operatorname{Ti}(0.39)>\mathrm{P}(0.16)>\mathrm{Mn}(0.04)$.

The average concentrations of trace elements $(\mathrm{mg} / \mathrm{kg})$ during the wet and dry seasons showed the following pattern $\mathrm{Ba}(450.81)>\mathrm{Zn}(149.66)>\mathrm{Pb}(144.9116)>\mathrm{Cr}$ $(50.04)>\mathrm{Cu}(36.47)>\mathrm{Co}$ (9.78).

\section{Discussion}

The ecotoxicological risk assessment used with SQGs and assessing the indices (EF, CF, and PLI) (Fig. 2, 3, and 4) revealed contamination by lead in all streams during wet and dry seasons valleys. The northwest stream valley, characterized by some industrial activities, and the stream valley crossing the abandoned mine sites were the most polluted by zinc and copper. $\mathrm{Cr}, \mathrm{Co}$, and $\mathrm{Ba}$ were found to be at minimal pollution during both the wet and dry seasons.

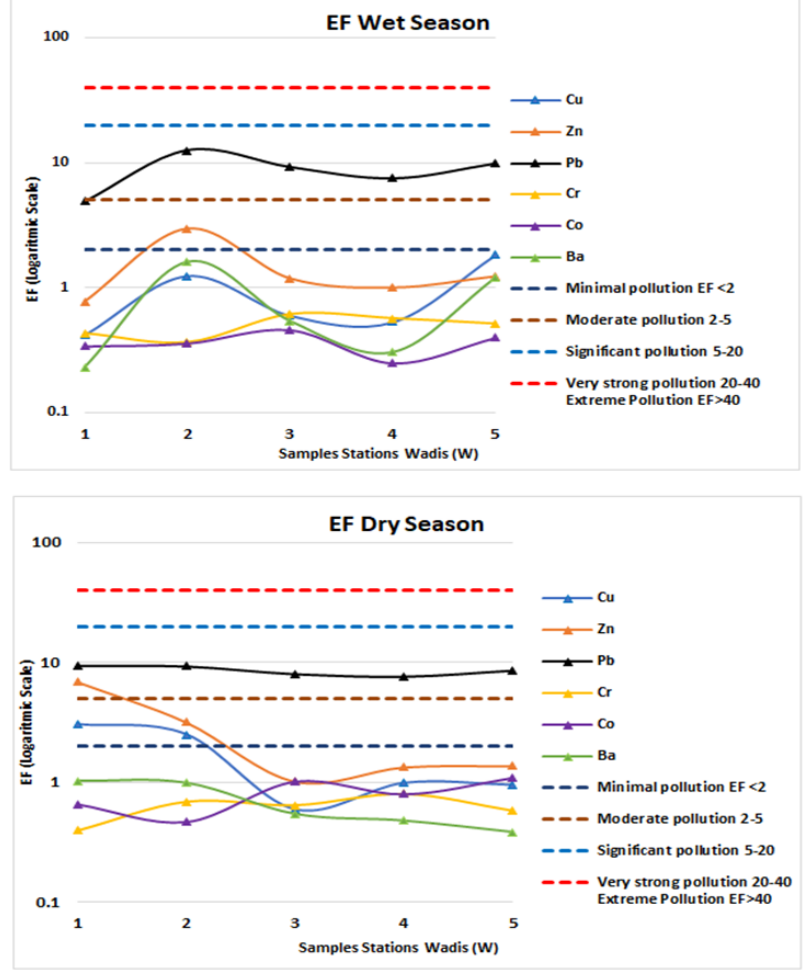

Fig. 2. Wet and dry enrichment factor.

In fact, the Marchica watershed drains rainwater from its four morphological structures by conveying wastewater from various industrial and mining activities through the main wadis that reach the Marchica lagoon, as reported by ABHM (2009) [7]. Some industries with main activities related to the steel industry were installed before implementing the national law on environmental impact studies and the discharge of their industrial waters without prior treatment, as reported by LNESP /BBN (2016) [14]. The irrigated agriculture of the Bouarg plain often uses excessive quantities of fertilizers, as reported by Re et al. (2014) [15] and Snoussi (2004) [16]. The iron ore deposit, part of which has been intensively exploited and 
abandoned without rehabilitation, can generate the production of acid mine drainage and the release of trace elements according to Bussière et al. (2010) [17] and impacts the Marchica lagoon through the Cabaillo wadi as reported by Khafouri and Talbi (2020) [18] and Lakrim et al. (2016) [19]

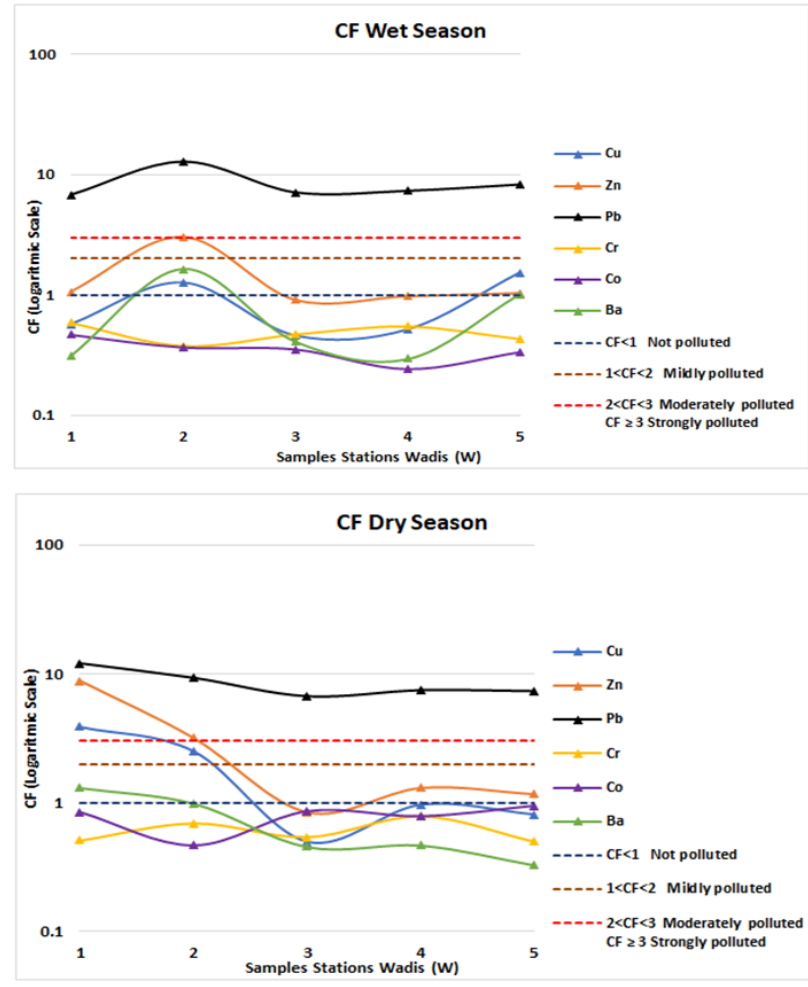

Fig. 3. Wet and dry contamination factor.

Similar pollution was found in the sediments Marchica lagoon during the same period of this study, as reported by Oujidi et al. (2021) [8]. This can confirm that the watershed has negatively impacted the Marchica lagoon despite the restoration actions around this Ramsar site during the last decade.

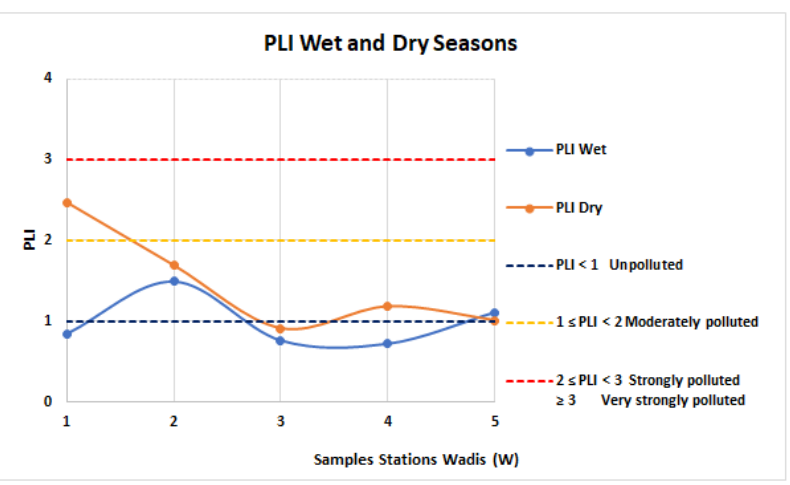

Fig. 4. Wet and dry pollution-load index.

\section{Conclusion}

This study confirms through the ecotoxicological risk assessment of the trace elements using pollution indices and SQGs, contamination of Marchica watershed by $\mathrm{Pb}$, $\mathrm{Zn}$, and $\mathrm{Cu}$. Therefore, an environmental management strategy is necessary, taking into account the rehabilitation of the abandoned mining sites, the rational use of pesticides and fertilizers in agriculture, and the environmental responsibility of industrial companies, especially those installed before the implementation of the national law on environmental impact studies.

\section{Acknowledgments}

The author thanks all partners of the Lag-Nad 2016 project who supported this work

\section{References}

1. M. Kennish and H. Paerl, "Coastal Lagoons," Marine Science, pp. 1-15, Jun. (2010).

2. M. J. Kennish, Ed., "Encyclopedia of Estuaries." Encyclopedia of Earth Sciences Series (2016).

3. M. Snoussi et al, "Effects of the construction of dams on the water and sediment fluxes of the Moulouya and the Sebou Rivers, Morocco," Regional Environmental Change, vol. 3, no. 1-3, pp. 5-12, Dec. (2002).

4. L. B. Korman et al, "Spatially distributed simulations of dry and wet season sediment yields: A case study in the lower Rio Loco watershed, Puerto Rico," Journal of South American Earth Sciences, vol. 103, p. 102717, Nov (2020).

5. O. Raji et al, Von Grafenstein, and A. Poujol, "Climate and tectonic-driven sedimentary infill of a lagoon as revealed by high resolution seismic and core data (the Nador lagoon, NE Morocco)," Marine Geology, vol. 398, pp. 99-111, Apr. (2018).

6. M. K. Bloundi et al, "Heavy metal contamination of coastal lagoon sediments by anthropogenic activities: the case of Nador (East Morocco)," Environmental Geology, vol. 56, no. 5, pp. 833-843, Jan. (2009).

7. ABHM (Agence du basin hydraulique de la Moulouya). Étude de protection du Grand Nador contre l'inondation. Rapport, 150 p. (2009).

8. B. Oujidi et al, "Seasonal and Spatial Patterns of Ecotoxicological Indices of Trace Elements in Superficial Sediments of the Marchica Lagoon Following Restoration Actions during the Last Decade," Diversity, vol. 13, no. 2, p. 51, Jan. (2021).

9. R. A. Sutherland, "Bed sediment-associated trace metals in an urban stream, Oahu, Hawaii," Environmental Geology, vol. 39, no. 6, pp. 611-627, Apr. (2000).

10. L. Hakanson, "An ecological risk index for aquatic pollution control.a sedimentological approach," Water Research, vol. 14, no. 8, pp. 975-1001, Jan. (1980).

11. D. L. Tomlinson et al, "Problems in the assessment of heavy-metal levels in estuaries and the formation of a pollution index," Helgoländer Meeresuntersuchungen, vol. 33, no. 1-4, pp. 566-575, Mar. (1980). 
12. R. L. Rudnick and S. Gao, "Composition of the Continental Crust," Treatise on Geochemistry, pp. 164, (2003).

13. D. D. MacDonald et al, "Development and Evaluation of Consensus-Based Sediment Quality Guidelines for Freshwater Ecosystems," Archives of Environmental Contamination and Toxicology, vol. 39, no. 1, pp. 20-31, Jun. (2000).

14. LNESP (Laboratoire National des Etudes et de Surveillance de la Pollution), Département de l'Environnement. Rapport Mise à jour du Bilan de Base National d'émissions/Rejets de Polluants (BBN). In MEDPOL program for the assessment and control of marine pollution in the Mediterranean, Report 88 pp. (2016).

15. V. Re et al, "Identifying the effects of human pressure on groundwater quality to support water management strategies in coastal regions: A multi-tracer and statistical approach (Bou-Areg region, Morocco)," Science of The Total Environment, vol. 500-501, pp. 211-223, Dec. (2014).

16. M. Snoussi, "Review of certain basic elements for the assessment of environmental flows in the Lower
Moulouya." IUCN International Union for

Conservation of Nature, Gland (2004).

17. B. BussiĖre, "Acid Mine Drainage From Abandoned Mine Sites: Problematic and Reclamation Approaches," Advances in Environmental Geotechnics, pp. 111-125, (2010).

18. K. Azzeddine and T. El Hassan, "Assessment of Metallic Contamination of Water Resources in the Area Around the Abandoned Mining Site of Ouixane (North East Morocco)," Proceedings of the 4th Edition of International Conference on Geo-IT and Water Resources 2020, Geo-IT and Water Resources 2020, Mar. (2020).

19. M. Lakrim et al, "Application Géomatique Pour La Cartographie De La Vulnérabilité Environnementale Engendrée Par Les Déchets Miniers De La Mine Ferrifere De Nador (Nord-est du Maroc)," European Scientific Journal, ESJ, vol. 12, no. 15, p. 287, May (2016). 